\begin{tabular}{|c|c|c|}
\hline $\begin{array}{c}\text { OPEN } \\
\text { JOURNAL } \\
\text { SYSTEMS }\end{array}$ & Journal of Hyperspectral Remote Sensing 02 (2012) 0250-036 & $\begin{array}{c}\text { Journal of } \\
\text { Hyperspectral } \\
\text { Remote Sensing }\end{array}$ \\
\hline ISSN:2237-2202 & & www.ufpe.br/jhrs \\
\hline
\end{tabular}

\title{
CLIMATE CHARACTERIZATION USING WATER BALANCE AND NDVI FOR CITY OF PAULISTA-PE
}

\author{
Luciana Mayla de Aquino França*; João Antonio dos Santos Pereira*; Josiclêda Domiciano \\ Galvíncio** \\ *Graduandos do curso de Bacharelado em Geografia. **Professora da Universidade Federal de Pernambuco. \\ Universidade Federal de Pernambuco, Departamento de Ciências Geográficas. \\ Av. Prof. Moraes Rego, 1235 - Cidade Universitária, \\ CEP: 50670-901 Recife/PE-Brasil. \\ Email: lucianamayla@hotmail.com \\ Received 05 October 2012; revised 01 November 2012; accepted 10 December 2012
}

\begin{abstract}
The State of Pernambuco is composed of five mesoregions established according to the IBGE (Brazilian Institute of geography and statistics), among them, the metropolitan region of Recife (RMR) that contains 14 municipalities. With urban development and technological, it became increasingly easy study that focuses on the physical characteristics of the environment, such as mulching, soil, hydrological and climatic characteristics. The destruction of plant cover to the urbanization is the factor that starts to trigger adverse processes in any region of the planet. Currently, are widely used techniques of satellite monitoring to track the environmental situation in the regions. With this, this article presents a study that evaluates the environmental and climatic characteristics, using tools such as the water balance and the NDVI for the municipality of Paulista - PE. The results showed that the municipality features compatible with the climate, being a moist spot and with dense vegetation.
\end{abstract}

Keywords: Municipality, NDVI, satellite monitoring, water balance.

\section{INTRODUCTION}

The characterization of a municipality is critical to understand the living conditions of a region, allowing a reliable assessment of its aspects. These assessments are very relevant to areas with high population density, such as the city of Paulista-PE.
According Florenzano (2007), Remote sensing is the technology that allows for images and other data from the surface by means of capture and record energy reflected or emitted by the surface. The uses of satellite images are excellent sources of data for the 
production of research data that is generated through image processing techniques.

According to Jensen (2009), the products obtained through remote sensing are widely used for the management and natural resource management. According SOMMER and SALDANHA (2012), the use of these images enables the analysis of geographic space in multitemporal character from the record of the interaction of electromagnetic radiation with different types of cover and land use. It's a snip of that reality integrated into a spatial context, allows us to analyze the processes of transformation of the territory.

Taking into account the characteristics of the northeastern coast, as well as the stage of urbanization of the cities that are around metropolitan areas, it is believed that there is a susceptibility of these municipalities tend to a serious degradation of their resources through the use of irrational soil, especially the most vulnerable, such as water and vegetation.

The aim of this paper is to characterize and describe some natural resources present in the municipality of Paulista, Pernambuco.

\section{MATERIAL AND METHODS}

\subsection{Caracterização e localização da área}

The municipality of Paulista is located Microregion of Recife and Mesoregion Metropolitan Region of Recife, Pernambuco state (Figure 1). Distant about $17 \mathrm{~km}$ from the capital. Borders on the municipalities of Abreu e Lima, Olinda, Recife, Igarassu, Paudalho and Camaragibe. It lies between $7^{\circ}$ $56 ' 27$ "south latitude and $34^{\circ} 52 ' 22 "$ west longitude according to the Geographic Coordinate System.

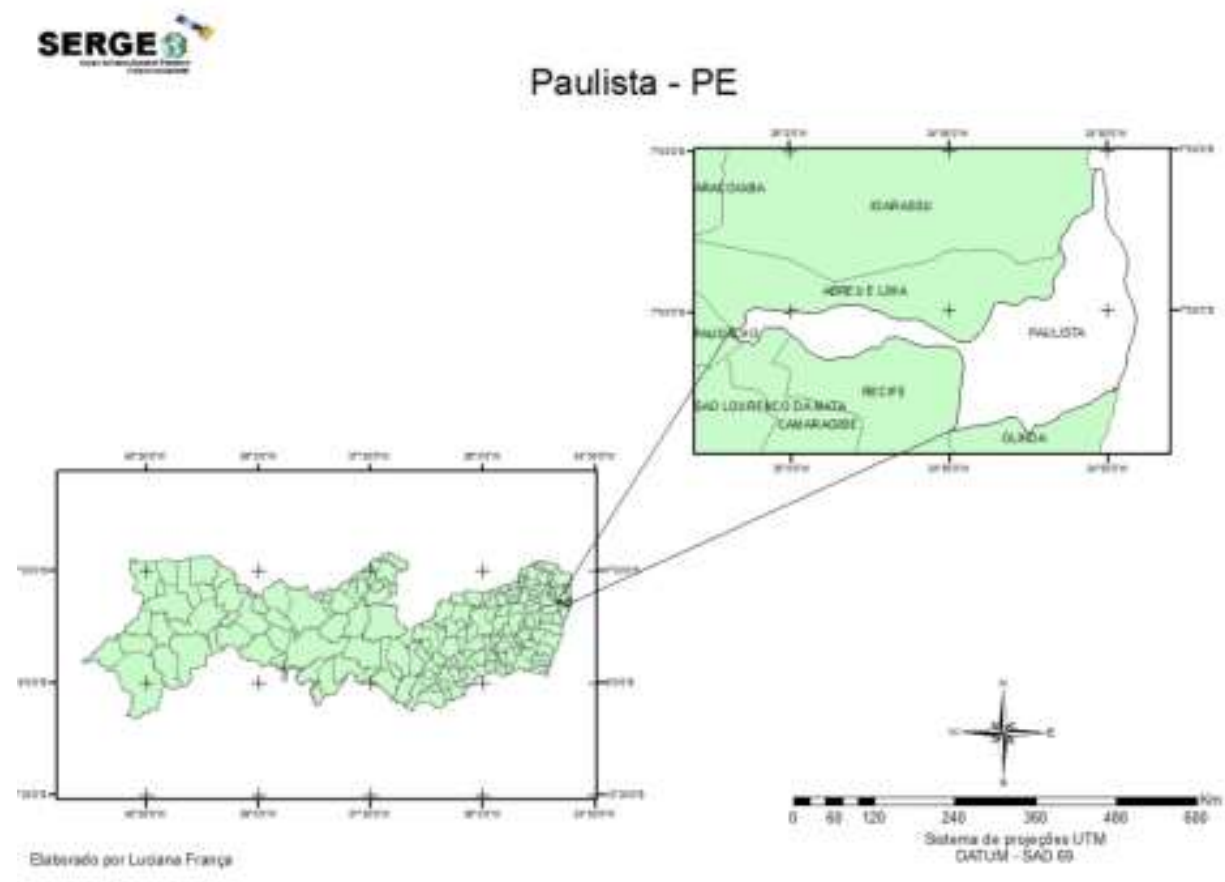


Figure 1 - Localization of the Paulista municipality.

The city of Paulista, as it is known, owes its name to the old mill master Manoel Navarro, a native of the captaincy of São Paulo. In its early days, was a district of Olinda, being elevated to a municipality and finally dismembered in 1938 (IBGE, 2010).

Comprising an area of $97.364 \mathrm{~km}^{2}$, presents features of relief, predominantly composed of the coastal plains, with an average height of $4 \mathrm{~m}$ near the beach and 40$50 \mathrm{~m}$ entering the continent. The rivers are perennial, the most important being: the Paratibe, that most of its length is in the municipality of Paulista and near the mouth of the Rio joins Fragoso forming the Rio Doce, which limits the municipality with Olinda, and the Rio Timbo which is located between Sao Paulo and Abreu e Lima, with its mouth at Praia de Maria Farinha.

Features a small vegetation remnant of Atlantic Forest and three forests that are located within the urban area or near them, they are considered ecological reserves, they are: The forest of Janga, of Jaguarana and Mata of Caetés. In the coastal strip, developed the mangrove vegetation, and in areas degraded by human action, close to beaches, disorderly occupation took the place of herbaceous vegetation.

Paulista is situated in an environment's climate '(tropical hot and humid with showers of autumn-winter) according to the Koppen climate classification.

The historical climatological average of the municipality of Paulista is $1951.6 \mathrm{~mm}$. Of these, $1614 \mathrm{~mm}$ occur between the months of March and August, representing just over $82 \%$ of rainfall in the region, featuring a concentration of rainfall in a particular time of year and the occurrence of a dry season between the months of September to February, as can be seen in Figure 2. 


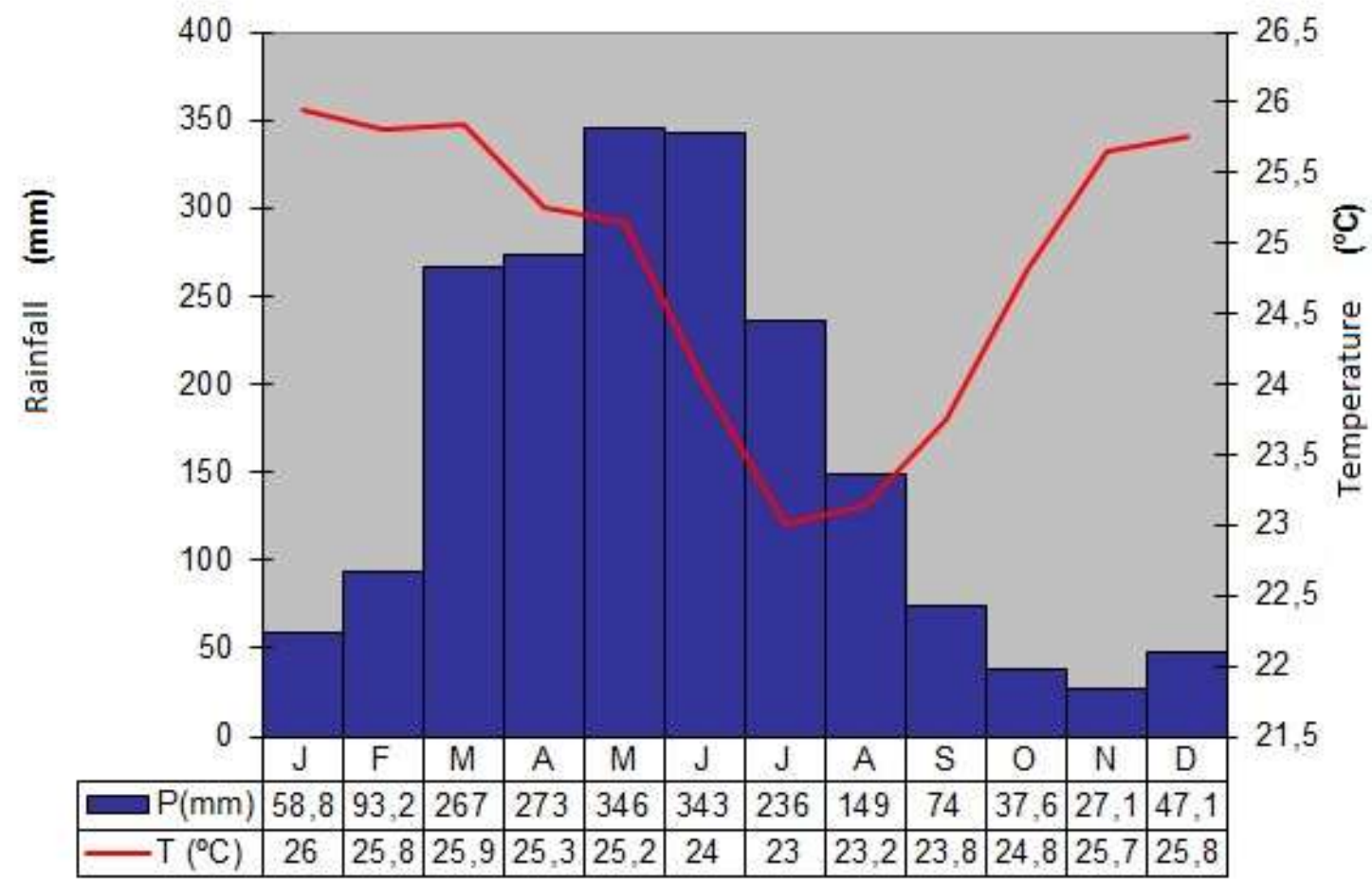

Figure 2: Climograma of municipality of the Paulista - PE.

Presents various soil types, the most common being the QMS (Quatzosas Marine Sands) present throughout the coastal strip, LA (Oxisol) present more within the municipality, HP (Podzols Hydromorphic) and SM (Mangrove Soils ) located near the river banks and the PA (Yellow Podzolic) as can be seen in Figure 3 (EMBRAPA SOILS, 2001). 


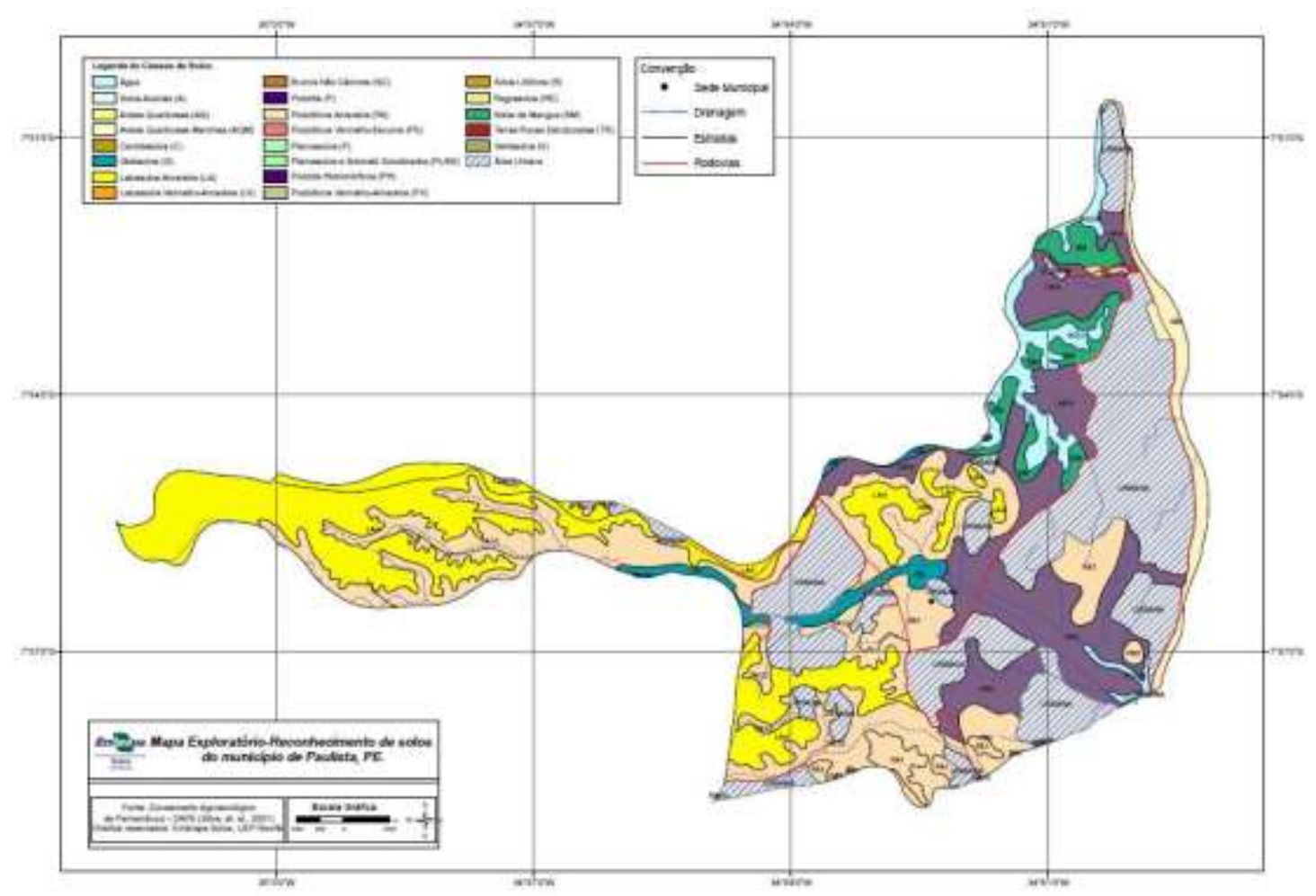

Figure 3: Soils of municipality of the Paulista. (EMBRAPA).

\section{Image processing}

We used satellite images from orbit and point 214/65, passing on August 26, 2006 Thematic Mapper (TM) satellite Landsat 5 acquired for free through the catalog of images from INPE (National Institute for Space Research). We also used data provided by the Agro-Ecological Zoning of Pernambuco (ZAPE). The data of temperature and precipitation for all years between 19611990, (Time actual- SOMAR Meteorology), with the aim of ensuring more reliable data to work.

With a series of historical data obtained for a better climate characterization was performed a climatic water balance proposed by Thornthwaite \& Mather (1955), considering a capacity of available soil water (CAD) 100mm. For this, we used the method of excel spreadsheets developed by Rolim and Sentelhas (1999).

For image processing and obtaining indices, we used the software ERDAS Imagine 9.3, and for the final assembly of the maps we used the software ArcGis 9.3 (both licensed by the Laboratory of Remote Sensing and GIS - SERGEO, Departamento de Ciências Geográficas - DCG, Universidade Federal de Pernambuco-UFPE).

The image processing for obtaining the contents was done in the following steps: Radiometric calibration - Radiometric calibration is obtained by the intensity of the radiant flux per unit solid angle and its concept can be compared to the concept of brightness, that is, an object is considered brighter greater its "measured radiance". These represent solar radiance reflected from each pixel per unit area, time, solid angle and 
wavelength, measured at the satellite bands 17 (Oliveira, Oliveira and Galvíncio, 2009). The radiance or radiometric calibration is obtained by the following equation proposed by Markham and Baker (1987). After, the reflectance and NDVI were calculated by Jansen equation (2009).

Through the image of NDVI was performed supervised multispectral classification, which classified the region in areas with vegetation, bare soil and water bodies (Chagas, GALVÍNCIO and PIMENTEL, 2010). The vegetated areas were classified following the methodology of Lawrence and Landim (2004). Each image pixel has a value, and this value gives the representation of the classes as shown in Table 1.

Table 1 - NDVI values used in the selection of classes of vegetation.

\begin{tabular}{|c|c|}
\hline Classes & NDVI \\
\hline Water & $<-0.1$ \\
\hline Bare soil & $0.01-0.1$ \\
\hline low vegetation & $0.1-0.2$ \\
\hline Sparse vegetation & $0.2-0.4$ \\
\hline Transition vegetation & $0.4-0.6$ \\
\hline Dense vegetation & $>0.6$ \\
\hline
\end{tabular}

The climate classification was calculated by Thornthwaite method, with base in humid index, Table 2.
Table 2 - Climate types second Thornthwaite (1955).

\begin{tabular}{|c|c|}
\hline Climate types & IH \\
\hline A - Superhumid & $\mathrm{IH} \geq 100$ \\
\hline B4 -Humid & $80 \leq \mathrm{IH}<100$ \\
\hline B3 - Humid & $60 \leq \mathrm{IH}<80$ \\
\hline B2 - Humid & $40 \leq \mathrm{IH}<60$ \\
\hline B1 - Humid & $20 \leq \mathrm{IH}<40$ \\
\hline C2 - Subhumid & $0 \leq \mathrm{IH}<20$ \\
\hline C1 - Subhumid dry & $-33,3 \leq \mathrm{IH}<0$ \\
\hline D - Semiárid & $-66,7 \leq \mathrm{IH}<-33,3$ \\
\hline E - Arid & $-100 \leq \mathrm{IH}<-66,7$ \\
\hline
\end{tabular}

\section{RESULTS AND DISCUSSION}

\subsection{Water balance}

In Figure 4, the water balance is shown for the series of years from 1961 to 1990 , considering the amount of CAD is $100 \mathrm{~mm}$. It can be seen that the six months of the year there is surplus water (EXC, blue) and six no water (DEF, red), where the Actual Evapotranspiration (ETR) is less than the potential evapotranspiration (ETP). During the rainy season (March-August) rainfall is used to replace water in the soil (REP, green), especially between the months of February and March, which is the completion of the dry season, thus beginning the period of water surplus. This means that the rains that occur during fall-winter are sufficient to cause saturation of soil by water. During dry season, the ground water withdrawal happens completely, starting water deficit period that runs from September through mid-February, where it begins to be reset. 
Taking into consideration that the rainiest months are May and June, is evident in Figure 4 extract water balance monthly to soil saturation reaches its maximum, i.e $250 \mathrm{~mm}, 150 \%$ more than the $100 \mathrm{~mm}$ that are taken as a basis. Already in the months where there is less rain, which are October and November, the water deficit goes from 0 to
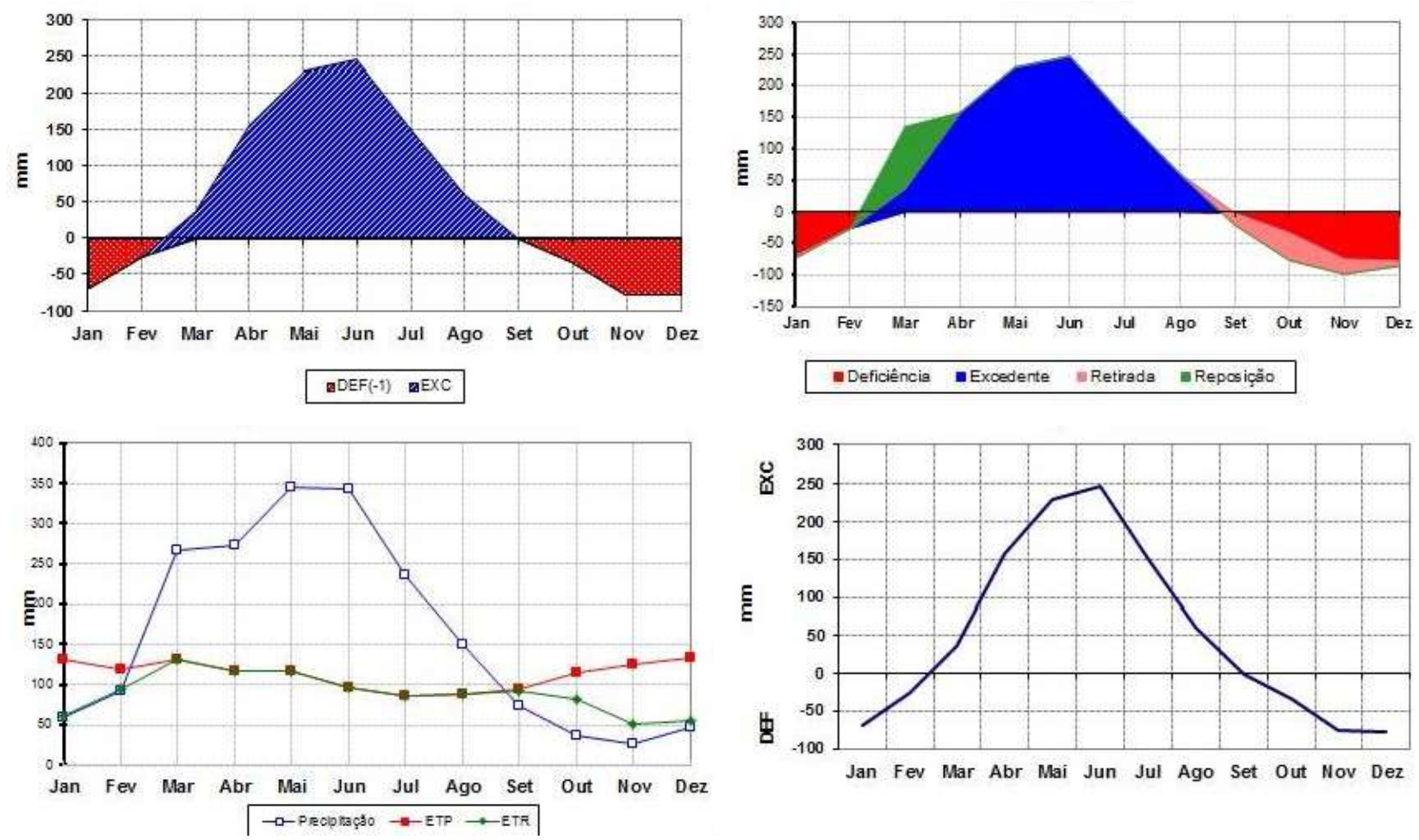

Figure 4 - Water balance of Paulista during the years of 1961-1990.

After water balance were obtain the following values for Surplus, Deficit and Potential Evaporation, Table 3.

We were obtaining the área in study the index, moisture index- $\mathrm{IM}=52,46$; humid index $-\mathrm{IH}=65,04$; arid index $-\mathrm{IA}=20,97$. almost -100 . With focus in the month in which he obtained the satellite image (August), there is a rainfall of $149.4 \mathrm{~mm}$ around, even with the smallest of the rainy season at the end of the month still has about $50 \mathrm{~mm}$ storage (ARM) . This month is where there is a decrease in the surplus and begins to be removed from soil water.
Table 3 - Surplus-EXC, Deficit-DEF and Potential Evaporation-EVP in Paulista-PE.

\begin{tabular}{|c|c|}
\hline Variável & Quantidade $(\mathrm{mm})$ \\
\hline EXC & 881,1 \\
\hline EVP & 1354,6 \\
\hline DEF & 284,1 \\
\hline
\end{tabular}

Analyzing the value obtained with the calculation of the moisture index, it is evident that the type Thornthwaite climate according 
to the city of Paulista is type B2, ie wet, because its value corresponds to 52.46 and is between $40 \leq \mathrm{IH}<60$. Taking into consideration or other aspects of classification created by Thornthwaite \& Mather in 1955, the climate of the municipality would be: B2sA'a ', ie, humid climate with moderate deficit in summer (IA between 10 and 20), megathermic $(\mathrm{EVP}(\mathrm{cm})>114)$, with annual rainfall of about $2,000 \mathrm{~mm}$.

\subsection{NDVI}

There is shown in Figure 3, multiple classes corresponding to the values already mentioned in Table 1. They are: Water, Bare Soil, Low vegetation, Sparse vegetation, Transition vegetation and Dense vegetation. Analyzing the values obtained after the classification, we can make the following analysis. Note that the water presents negative values, reaching its maximum at -0.008 . The largest stretch of water corresponds to Timbo River, and smaller, farther east, refers to Rio Paratibe very close to the mouth, since even during his journey is constantly surrounded by dense vegetation. The area of exposed soil / urban area is restricted to the nearest ocean, featuring the most densely populated area of the city. The whole coastal stretch is composed Quatzosas Marine Sands, which have deep soils, and somewhat excessively drained loamy. Also notable is the presence of exposed soil / urban area entering the interior of the city, where there are ecological reserves, with the presence of soils and Podzolic Yellow Podzols Hydromorphic (EMBRAPA, 2001). The values obtained for the exposed soil reaches a peak in 0813. The sparse vegetation remained with values 0.151 0.271 was absent where there is the largest urban concentration. Value 0.271-0.473 are related to Sparse vegetation, with upright plant habit, while thin has a more herbaceous. From 0.473-0.663, we have the transition vegetation, which the city can be found nearby, or even mixed with denser vegetation. For higher values found, $0.663-0.813$ is characterized dense vegetation, which is restricted to areas of ecological reserves, mainly of Paratibe (further west), where there is little urban occupation and kills more is preserved. In the case of the municipality of Paulista, the values found in NDVI for this last class of vegetation are characteristic of wetlands. 


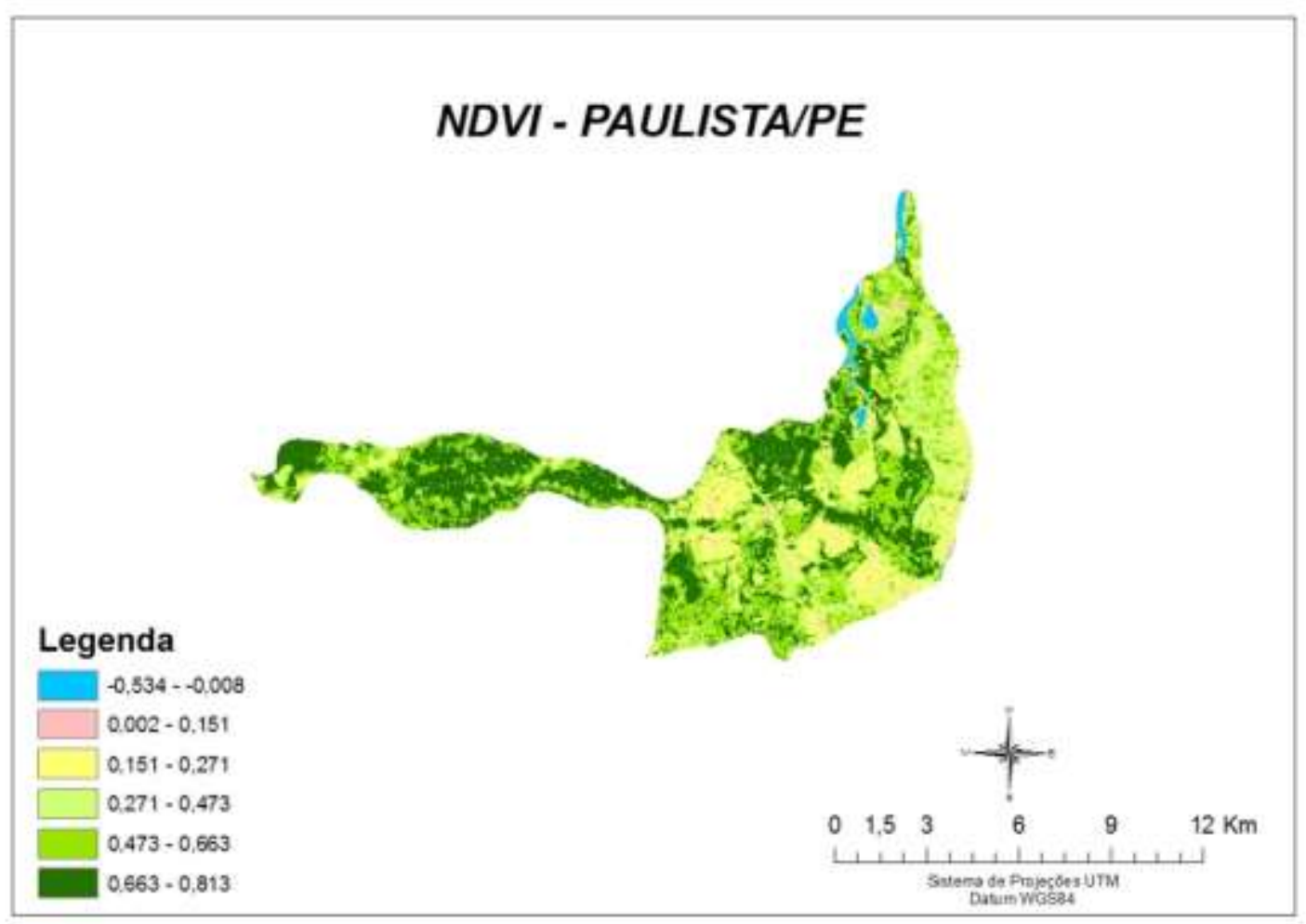

Figure 5 - NDVI of municipality of the Paulista.

In Figure 6, there is a percentage of composed of transition vegetation, being each class that was obtained through the followed by dense vegetation, sparse NDVI for the municipality of the Paulista. vegetation, low vegetation, Bare Soil and One sees clearly that most of the city is

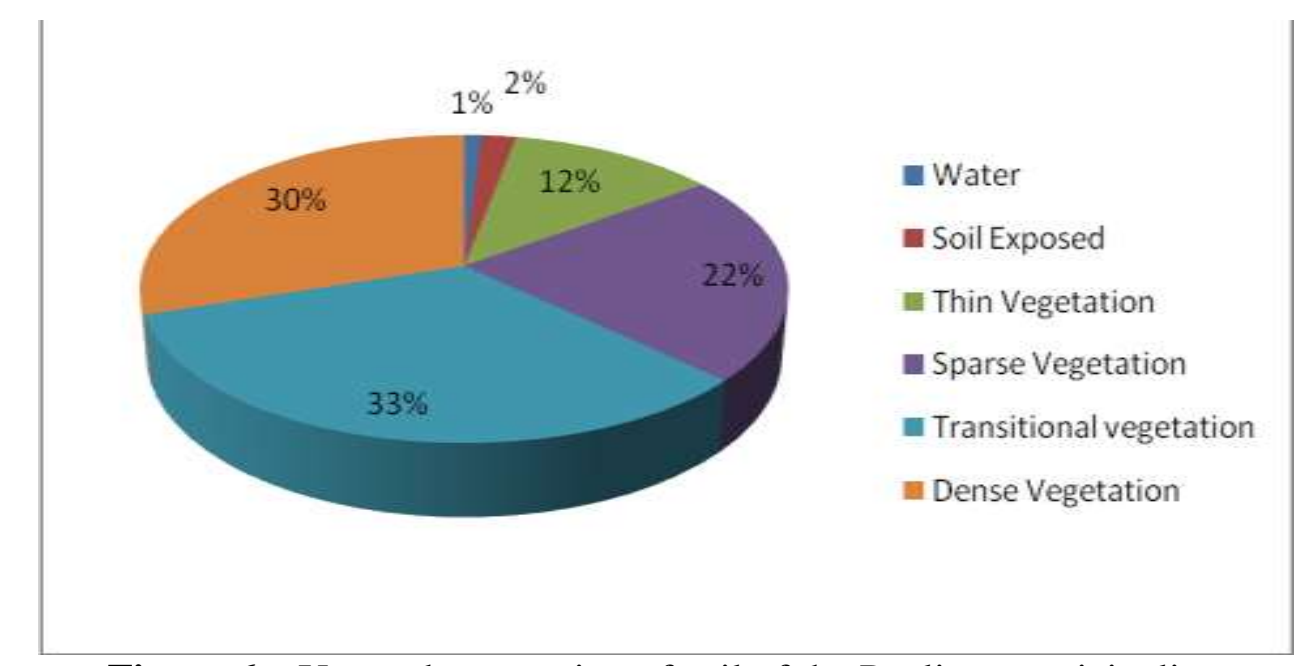

Water.

Figure 6 - Use and occupation of soil of the Paulista municipality. 


\section{CONCLUSION}

In general, the municipality has a humid, with vegetation that reflects this characteristic. By analyzing the water balance performed, it appears that municipality does not differ much from the characteristics of tropical Brazil, leaving only water deficit during periods of spring and summer, where there is dry season and lower values of precipitation.

The saturation of soil $(100 \mathrm{~mm})$ is still at beginning of rainy season, reaching its peak at height of rainy season (June-July). The highest value of potential evapotranspiration is obtained in December, since November is the month with the lowest rainfall. After this study, it is seen that the Remote Sensing and GIS are very useful tools to analyze and monitor physical environment. In this paper, this method helped to make a relationship between climate and vegetation of the city, which despite being inserted into one of the largest metropolitan areas in the country, still has high levels of vegetation. The concerns that led to this study were confirmed, as we observe that the weather directly affects the characteristics of the vegetation of a site. These characteristics were obtained by NDVI, which proved to be an effective method for the analysis of anthropogenic environmental conditions.

\section{ACKNOWLEDGMENT}

The authors want to leave here expressed their thanks to the members of the
Laboratory of Remote Sensing and GIS SERGEO, Professor Dr Josiclêda Domiciano Galvíncio by moments of guidance and to $\mathrm{CNPq}$ for the financial support the structure of the SERGEO through the process number 558074/2009-0.

\section{REFERENCE}

Allen, R. G.; Tasumi, M.; Trezza, R.; Bastiaanssen, W. (2002). Surface Energy Balance Algorithms for land (SEBAL). Idaho Implementation - Advanced training and user's manual, v. 1.0.

Chagas, M.; Galvíncio, J.; Pimentel, R. (2010). Avaliação da Dinâmica Espectral da Vegetação de Caatinga. Revista de Geografia (Recife), Pernambuco, Brasil, 25509.

Ferreirra, W. P. M. (2005). Caracterização climática da área de atuação da Associação Brasileira de Agronegócios de Ribeirão Preto (ABAG-RP). Comunicado Técnico Embrapa. Campinhas-SP.

Florenzano, T. G. (2007). Iniciação em Sensoriamento Remoto; Oficina de textos, $2^{\mathrm{a}}$ edição.

IBGE. (2010). Censo Demográfico. Disponível em: 〈www.ibge.gov.br>. Acesso em 21 de Maio de 2012. 
Instituto Nacional de Pesquisas Espaciais (INPE). (2012). Disponível em: http://www.dgi.inpe.br/CDSR/.

Jensen, J.R. (2009). Sensoriamento Remoto do Ambiente - Uma Perspectiva em Recursos Terrestres. São José dos Campos: Parêntese Editora.

Lourenço, R.W.; Landim, P.M.B. (2004). Estudo da variabilidade do "Índice de Vegetação por Diferença Normalizada/NDVI" utilizando krigagem indicativa. Holos Environment, 4: 38-55.

Machado, C. C. C.; Oliveira, T. H.; Galvíncio, J. D. (2010). Interferência Climática e do Homem na Cobertura Vegetal da Bacia Hidrográfica do Rio Capibaribe - PE. Mudanças climáticas e recursos hídricos: aplicações no estado de Pernambuco. Editora Universitária - UFPE.

Markham, B. L.; Barker, L. L. (1987). Thematic mapper bandpass solar exoatmospherical irradiances. International Journal of Remote Sensing, v.8, n.3, p.517523.

Oliveira, J.C.F.; Oliveira, T.H.; Galvíncio, J.D. (2011). Análise Espaço Temporal do Fenômeno de Ilhas de Calor no Bairro de Boa Viagem, Recife-PE e Entorno, Através de imagens TM Landsat. Mudanças Climáticas e
Ambientais, capítulo 9, página 153; Editora Universitária-UFPE.

Rolim, G. S.; Sentelhas, P. C. (1999). Balanço Hídrico Normal por Thornthwaite \& Mather (1955). Piracicaba. ESALQ.

Silva, B.B. (2011). Balanços de radiação e energia com imagens Landsat. Programa de Pós-Graduação em Geografia e Programa de Pós-Graduação em Engenharia Civil, Universidade Federal de Pernambuco.

Silva Sá, I.; Galvíncio, J.; Moura, M.; Sá, I. (2012). Avaliação da Degradação Ambiental na Região do Araripe Pernambucano Utilizando Técnicas de Sensoriamento Remoto (Evaluation of the Environmental Degradation in the Araripe from Pernambuco Area Using Techniques of Remote Sensing). Revista Brasileira de Geografia Física, Pernambuco, Brasil, América do Sul, 41704.

Sommer, J.; Saldanha, D.. (2012). Análise Temporal do Uso e Cobertura dos Solos no Município de São José dos Ausentes, Rio Grande do Sul, Brasil (Temporal Analysis of Use and Land Cover in the Municipality of São José dos Ausentes, Rio Grande do Sul, Brazil). Revista Brasileira de Geografia Física, América do Sul, 51605.

Thornthwaite, C. W.; Mather, R. J. (1955). The water Balance. New Gersey: Laboratory of Climatology, v. 8, 104 p. 
Santos, J. C. P; Luz, L. R .Q. P... [et al.] ZAPE digital. (2000). Zoneamento (2001). Recife: Embrapa Solos - Unidade de Agroecológico do Estado de execução de Pesquisa e Desenvolvimento Pernambuco/Fernando Barreto Rodrigues. UEP Recife; Governo do Estado de Embrapa. CD digital. Pernambuco (Secretaria de Produção Rural e Reforma Agrária). 